\title{
Covert Operations, Wars, Detainee Destinations, and the Psychology of Democratic Peace
}

Running head: Covert Wars and Democratic Peace

Word Count: 10,991

Authors' Note: Original data files and experimental materials are on file at the Open Science Framework. Retrievable from osf.io/4n85y 


\begin{abstract}
We explore US covert forcible actions against democratic governments and their citizens and show that inter-democratic use of covert force is common and can be accommodated within the theory of democratic peace. Grounded in the Perceptual Theory of Legitimacy, we argue that democracies are constrained by public perceptions of their legitimacy from overtly aggressing against other democratic states. When democracies desire to aggress against their democratic counterparts they will do so covertly. We test the assumptions of the theory and its implication with (1) laboratory studies of the conflation of democracy with ally status, and (2) historical analyses of covert militarized actions and prisoner detention, which show that US forcible actions, when carried out against democracies and their citizens, are carried out clandestinely.
\end{abstract}

Abstract: 123 words 


\section{Covert Operations, Wars, Detainee Destinations, and the Psychology of Democratic Peace}

The dearth of open militarized disputes between advanced democracies does not mean that democratic foreign policies direct no violence against each other. Advanced democratic states have a documented history of employing coercion against isolated and weaker democracies. The security and economic interests of advanced democracies, the expectation of an easy victory, and perceived political dissimilarities can supersede the normative pull of the democratic concord (Henderson 2002; James and Mitchell, 1995; Kim 2005; Reiter and Stam 2002; Van Evera 1990).

The "war on terror" has put the democratic peace theory (DPT) to yet another test by marking a notable shift in the powers of Western security services and the range and nature of their clandestine operations. Pressed to develop a policy in response to the events of $9 / 11$, the Bush administration's policies afforded security services unprecedented levels of autonomy to kill, detain, transfer to other jurisdictions, and otherwise abuse the rights of terrorist subjects. Reports from the US Senate and the Bush administration's secret memorandums revealed that the subjects of extraordinary rendition and victims of enhanced interrogation techniques included citizens of democratic states (Ramsay 2010; Senate Armed Services, 2008). European Parliament investigations uncovered cooperation between European secret services and the US extraordinary renditions programs (European Parliament, 2007). The extrajudicial transfers of terrorist suspects continued with reduced frequency under the Obama administration, which has also given the security services discretion in the apprehension and killing of "terrorists", including by targeting suspects with drones.

Why would democracies engage in violent covert actions against other democratic states and their citizens? The variety of inter-democratic violence and coercive actions short of war 
have been viewed as a critical challenge to DPT arguments, especially its normative propositions (Downes and Lilley 2010). American military interventions against other democratic regimes constitute "the starkest empirical anomalies for democratic peace" (Kinsella 2005, 455). If the US government uses force covertly against other democracies, how can we reconcile this with of the absence of overt war between democratic states?

DPT scholars have tried to resolve these apparent discrepancies in inter-democratic violence and covert operations in three ways. First, there is a definitional issue; one may argue that covert operations fall below the threshold for violence and do not amount to war. Second, one can impugn the democratic nature of a state targeted for violence; they are perceived as nondemocratic by the aggressing state. Finally, the very nature of covert operations-hidden from the public eye - make them consistent with the democratic peace because they imply the concern of the democratic leaders with public opinion and fear of political consequences for the unpopular attack on another democracy (Kim \& Kundt, 2012).

The studies in this paper develop arguments consistent with the third "clandestine hypothesis." We contend that the inter-democratic use of covert force can be accommodated within the principles of liberal democratic peace. We foreground liberal ideology, and discuss how the expectations of congruence between individuals' liberal preferences and democratic governments' policies constitute an important part of their thinking. Our arguments are based on the Perceptual Theory of Legitimacy (PToL, Crandall \& Beasley, 2001): Decisions to use covert action results from the normative and institutional constraints through the dynamic process of sustaining popular consent in the legitimacy of democratic government. The latter is constrained by public perceptions of its legitimacy from overtly aggressing against democracies. To the extent that democracies desire to aggress against other democratic actors they will tend to do so 
covertly.

We first establish the perceptual tendency for citizens to see US allies as more democratic (Study 1), and we establish the causal relationship between these tendencies through a controlled experiment (Study 2). We then demonstrate a behavioral tendency on the part of the US to prefer covert action when aggressing against more democratic targets. We examine this in two contexts: U.S. covert interventions 1949-2000 (Study 3), and US renditions of detainees in the war on terror (Study 4).

\section{Theory}

$D P T$

The assertion that democracies, while no less war prone, rarely fight one another has generated an avalanche of empirical and theoretical research (Maoz and Russett 1993; Oneal and Russet 1999a; Owen 1994) and stimulated theoretical and methodological discussions (Morgan and Schwebach 1992; Mousseau 2009; Rosato 2003; Ungerer 2012). The structural or institutional accounts of DPT identify various democratic institutions, procedures, and processes that enhance the accountability of policy makers to the public, legislatures, and interest groups. As a result, use of large-scale violence is both politically costly and inefficient (deMesquita et al., 1999; Rosato 2003; Ungerer 2012; for the critique of institutional explanations see Maoz and Russett 1993; Morgan and Schwebach 1992). Normative accounts of democratic peace maintain that democratic culture, liberal ideology, and democratic norms, once externalized, steer democracies away from the use of violence against their own people (Rosato 2003). Recent years have seen the advent of several new accounts of inter-democratic peace. The informational hypothesis is that the openness and transparency of democratic institutions enable them to send and receive costly signals, which allows democracies to resolve disputes at lower levels of 
hostilities (Levy \& Razin 2004). The preferential logic, derived from social identity theory, posits a strong correlation between domestic institutions and foreign policy choices and expects democracies to have similar foreign policy preferences. Finally, the perceptions-based argument requires democracies to perceive their counterparts as similarly democratic for peace between them to hold (Owen 1997; Oren 2013).

Although, debates about what constitutes a war and what counts as democracy continue (Owen 1994; Tures, 2002), critics of DPT argue that both institutional and normative mechanisms should avert democracies from the use of direct physical force in any form, including war, military interventions, assassinations, small-scale aggression, torture, and the threats of force (Downes \& Lilley 2010; Layne 1994; Reiter \& Stam 2002). Contrary to these expectations, democracies have frequently employed a wide range of coercive behavior in their relations with other democratic states. Covert use of force has become a hotly contested instrument of contemporary statecraft advocated by security advisers in democratic nations. The US in particular has resorted to covert military activities and clandestine interventions against other elected governments, and supported coercive actions against individuals under the pretext of the "war on terror" (Forsythe 1992; Kegley \& Hermann 1995; Kim \& Kundt, 2012).

The significance of these debates has been elevated by the close interplay of DPT scholarship with security strategies and foreign policies of democratic states (Ish-Shalom, 2008). In the US, the idea of democratic peace informed the Clinton administration's strategy of "democratic enlargement" for fostering international peace and became the cornerstone of the security strategy under the Bush administration. However, the use of DPT arguments for legitimizing US intervention in Iraq was followed by the revelations of torture of POWs, drone 
wars, and several covert operations accompanying the American quest for international democratization, rekindling debate about the conduct of democracies (Goldstein, 2011).

Some contend inter-democratic clandestine operations short of open war constitute an aberration for DPT, particularly its normative logic (Rosato 2003; James \& Mitchell 1995; Van Evera 1990). We differ; inter-democratic covert operations involving the use of force can be accommodated within DPT. In the context of covert operations and extraordinary renditions against other democratic states and their citizens, we show how decisions concerning war and peace are motivated by the interest in building and sustaining popular consent in the legitimacy of democratic government.

\section{Perceptual Theory of Legitimacy}

The core of democratic peace relies on liberal ideas about autonomous individuals capable of defining and pursuing their interests in self-preservation and wellbeing (Doyle 2005; Oneal \& Russett 1999). Freedom is required for the pursuit of these interests, and peace is a prerequisite for freedom. Since violence and coercion are inimical to freedom, individuals are predisposed to value peace (Owen 1994). In liberal political theory, individuals and their interests are thought to exist prior to politics, but they can advance their interests through collective action and participation in the institutional framework of a democratic state (Moravcsik 1997). The underlying interests of democratic citizens are not only expected to constrain state policies but also to define the social identity of democracy. Together, the social identity, interests, and preferences specify the legitimate order in a democratic state (Moravcsik 1997).

A government's legitimacy can be construed as a result of a psychological process, where individuals' perceptions of the moral worth of the government and its actions constitute 
elemental parts of their perceptual field. According to the PToL, legitimacy is conferred when the moral value of a nation and governmental actions are consistent with each other (roughly equal) (Crandall \& Beasley 2001). The two essential propositions of the PToL relevant to the perceptions of legitimacy of a democratic government and its international conduct are "structural balance" and "unit relationship" (Crandall et al., 2007). The principle of structural balance, which also underpins the perceptual logic of DPT (Owen 1997), stipulates that individuals are motivated to have an affectively uniform impression of their own states or other nations and their peoples; citizens wish to avoid ambivalence and inconsistency among related objects or events. People are motivated to put positive elements together and negative elements together: democracies are "good" (Sen, 1999) and all things democratic are good as well, whereas non-democracies are bad (or at least worse than democracies), and non-democratic governments and people have lesser moral value (Falomir-Pichastor et al., 2011).

Affective consistency is important only among objects that belong together (e.g., actors and their deliberate choices, citizens and their government). Because citizens in a democracy are perceived to freely choose their governments, the government is in a "unit relationship" with the populace. The government and citizens are viewed as belonging together, or as two parts of the "whole." By extension, the actions of the governments epitomize the choices of the citizens. If, however, the government policies go against the core of the state's social identity represented in the citizens' true interests in freedom, material wellbeing, and peace, individuals will experience affective inconsistency (how can a "good" government engage in "bad" behavior?). This perceptual inconsistency will force individuals to expend mental energy for a potentially unpleasant reevaluation of their cognitive and affective elements ("Is this legitimate leader of a good nation really a good person?"); inconsistency leads to the perception of illegitimacy. 
The PToL belongs to the family of consistency theories — such as balance theory (Heider 1958) and cognitive dissonance theory (Festinger 1957) — which are premised on the idea that people are motivated to seek coherent attitudes, beliefs, values, and behaviors. Inconsistencies result in aversive feelings or discomfort, and motivate people to make relevant cognitions consistent with one another. Cognitive dissonance theory has been prominent exemplar of consistency theories applied to the study of international relations and foreign policy (Jervis 1976; Larson 1985; Snyder 1978). By contrast, the PToL draws more directly from Heiderian balance theory, in three particular ways. First we are more interested in the overall inconsistencies that are likely to be perceived as imbalanced, rather than the individual-level factors or situational contexts that are more likely to give rise to those inconsistencies. Second, we do not specify the degree of intensity with which individuals will feel cognitive inconsistencies, as does most cognitive dissonance theorizing, only that inconsistencies will give rise to efforts to reduce them. Thus drawing on balance theory offers a more concise approach. Third, and most important, we are positing a perceptual "unit relation" between governments and citizens, which is conceptually more similar to balance theory precepts, as cognitive dissonance theory does not directly specify which cognitive elements will be involved in arousing dissonance.

In sum, the PToL proposes that there is a desire to view things that belong together as affectively consistent. People are motivated to restore consistency either by changing the affective value of an object, or by changing the connectedness of objects (e.g., Beasley and Crandall, 2004; Heider, 1958; 1990). Legitimacy arises out of this consistency—when inconsistency persists, legitimacy suffers. Applied to democracy, the legitimacy of a democratic government arises out of the consistency of its institutions and actions with citizens' 
expectations. A democratic government, for example, is expected to allow the public to be represented in the decision making process, to have a voice in its assessment and evaluation, and to allow some control over the outcomes of governance (Lipset 1959). Individuals then extend their support to the government in exchange for institutions and policies that jibe with their preferences. These institutions and policies, as well as the government that epitomizes them, are harmonious in their value, and thereby legitimate. Since democratic governments are concerned about their legitimacy, their conduct regarding the use of force will be motivated in part by an effort to realize individuals' interests in freedom and peace.

We do not assume that citizens and leaders of democracies share the same interests and preferences, as many other DPT scholars do (see Hermann and Kegley 1995; Rosatto 2003). Even if the preferences of democratic citizens and leaders were uniform, it is not uncommon for the leaders' preferences to be in tension with what they view as their state's immediate political goals. The originator of republican peace, Immanuel Kant, himself feared that the republican governments would occasionally engage in non-liberal international conduct cloaked in liberal justifications (Doyle 1995). In the parlance of international relations, states' preferences are causally independent of their strategies and tactics. Event if the democratic states' preferences represent their citizens' true concerns, their strategies and tactics are affected by the immediate political aims and external circumstances made up of threats, opportunities, and incentives (Moravcsik 1997; Rousseau, Gelpi, Reiter \& Huth, 1996).

When faced with a dilemma of reconciling the incompatible preferences and policy options dictated by their state's immediate political interests, democratic leaders will be constrained by the preferences of their people. While it has already been acknowledged that perceptions matter in the democratic comity, the jury is still out on precisely how the process 
works to constrain belligerency among democracies. Our argument aligns with that of Jerrod Hayes (2012), who explains democratic peace through the mechanisms of constraints placed on political elites by the perceptions and expectations of their constituents unwilling to pick fights with members of a putative "in-group" as it arouses cognitive inconsistency in people. Hayes, however, does not articulate how these perceptions are created and sustained. According to the PToL, democratic citizens have positive evaluations of democracy (Falomir-Pichastoret al., 2012) and they are connected by a unit relationship with their governments and other democratic nations. For reasons of cognitive consistency, they think that other democracies and their citizens are good. War against a democracy creates a highly inconsistent, deeply imbalanced perception, and is thus illegitimate. Democratic citizens also deserve commensurately positive treatment; their abuse or mistreatment is inconsistent with democratic comity.

Since democratic governments are both constrained by and concerned with their popular legitimacy ${ }^{1}$, they will engage in acts of coercion and violence that are both psychologically and socially inconceivable only to the extent that they are able to (1) make their actions seem legitimate or (2) merely conceal them. When the creation of popular consent for openly coercive policies appears unattainable using the elaborate myths of legitimization, the democratic government may resort to covert force to evade ex ante due approval process and to avert the $e x$ post de-legitimation and electoral retribution (Reiter and Stam 2002).

Therefore, in relations with other democracies, democratic states will be likely to substitute non-military and covert operations for direct military confrontation when these types of coercion serve their governments' immediate political aims (Morgan and Palmer 2000; Most

\footnotetext{
${ }^{1}$ Elites in democratic states feel constrained based on their perception of what the public will and will not accept. An extensive literature in public opinion indicates that "... [prospective] public opinion exerts a constant influence as leaders anticipate potential future public reactions to their current policies" (Baum \& Potter 2008: 55). Variations in dependence on public consent are systematically related to propensity to initiate conflict (Reiter \& Tillman 2002).
} 
and Starr 1984; Palmer, Wohlander, Morgan 2002). As a consequence, the connection between the democratic peace and covert operations will be inverted. This is the "clandestine hypothesis:" democratic states will use covert types of force against each other more often precisely because they desist from engaging in the open military hostilities and war with one another, as the overt use of force hurts legitimacy of democratic governments. ${ }^{2}$

\section{The Studies}

In this paper we present four studies that test the causal mechanism of inter-democratic covert force informed by the PToL. In Study 1, we test whether US students perceive a correlation between the democracy level of a nation and its ally status. In Studies $2 \mathrm{a} / \mathrm{b}$ we test whether knowing a nation is an ally causes US students to perceive it as a democracy, and that knowing a nation is a democracy causes US students to perceive it as an ally. In Study 3, we compare US militarized actions against democracies and non-democracies, to see how often these two kinds of disputes are carried out covertly. In Study 4, we compare the democracy level of the home nations of detainees in the US "war on terror," and test whether more democratic "origins" increase the probability of extraordinary rendition.

\section{Study 1: Perceptions of Allies and Democracies}

To the extent that individuals view the US as both good and democratic, they should also view countries related to the US in a more favorable light; allies should be seen as democratic, and democracies should be seen as allies. These results should manifest as a positive correlation

\footnotetext{
${ }^{2}$ Although we make no explicit claims regarding the "rationality" of state behavior and the use of covert operations, the PToL predicts a different frequency of covert activities when democracies are dealing with democratic versus non-democratic governments. A rational choice of foreign policy tools would expect there to be no difference in the rate of covert force by democracies toward other democratic or non-democratic states. The use of covert force toward democracies implicates leaders' sensitivity to public perceptions, which the PToL explains.
} 
between perceptions of the US, perceived alliance with and similarity to the US, and perceived level of democracy among the countries of the world.

Method

Data came from 190 self-identifying US citizens in an undergraduate course at the University of Kansas in the spring of 2007. Participants were told they would be filling out a questionnaire regarding their perceptions of several different countries within the United Nations.

Each participant received a one-page questionnaire consisting of five or six UN member states grouped at random. The 33 different questionnaires provided brief innocuous information for each target nation (e.g., location, population, GDP, exports). In all 190 of the 192 member nations were rated (excluding the US and the Democratic Republic of the Congo, because of its name).

Participants answered four questions: How important is this country on the world stage, how similar is this country to the United States, how democratic is this country, and what level of relation does this country hold with the United States. Participants then completed two items examining their perceptions of the United States: "The United States is the greatest nation in the world," and "How democratic is the United States government?"

Results and Discussion

Perceptions of democracy and alliance with the US were correlated, $r=.23, p<.001 n=190$ (see Figure 1). Because Iraq was an outlier and relations with the US were complex in 2007, we removed it, with $r=.26, \mathrm{p}<.001 n=189$. As perceived levels of either democracy or alliance increased so did the other in way that promoted a balanced state. The perception of a nation's alliance with the U.S. was correlated with perceived similarity to the US $r=.63$ (see Table 1).The 
target nation's perceived importance and alliance with the US were correlated $r=.24$, and there was a correlation between a target nation's perceived importance and similarity to the US, $r=.69$.

Consistent with the PToL, our participants believed that US allies were similar to the US, they are democracies and were important on the world stage; our participants showed consistency when forming their perceptions of foreign governments and global relationships. These correlations are not large, and they cannot demonstrate causal linkages. In Study 2a, we experimentally manipulate the historical democracy status of Iran, and measure whether or not students perceive it to be an ally when it is a democracy. Simultaneously, in Study $2 b$ we perform the mirror image of this experiment by manipulating whether or not Iran was an ally, and measuring whether or not students perceive Iran to be a democracy.

\section{Studies 2a and 2b: Causal Connection Between Democracy and Ally Status}

Design and participants. Two simultaneous and independent experiments were run. Each participant read a vignette about Iranian history and its relations with the US across two decades, the 1970s and the 1980s. In Study 2a, we manipulated the ally status of the US and Iran, and measured participants' perception of Iran's democracy level. In Study $2 b$, we manipulated the democracy level of Iran, and measured participants' perception of Iran's ally status with the US. Within each study, there were two conditions. In Study 2a, Iran was described as an ally in the 1970s and an adversary in the 1980s, or alternatively an adversary in the 1970s and an ally in the 1980s. Similarly, in Study 2b, Iran was either described as a democracy in the 1970s and an autocracy in the 1980s, or as an autocracy in the 1970s and as a democracy in the 1980s.

In this way, democracy or ally status are manipulated within subject, so that each person in Study 2a evaluates Iranian democracy both when an ally and an adversary; each person in Study $2 \mathrm{~b}$ evaluates Iranian-US ally status both as a democracy and as an autocracy. This 
enhances the statistical power of the experiment, and provides what is an independent replication built into the study. Because our participants were mostly ignorant of Iranian history, whether we describe Iran as a democracy (or an ally) in the 1970s vs. the 1980s is relatively arbitrary, and so the two conditions within studies serve as independent replications of each other. The participants were $113 \mathrm{KU}$ undergraduates, 54 in Study 2a, and 59 in Study $2 \mathrm{~b}$.

To test knowledge about Iran, we asked four general knowledge questions. Two were open-ended: the most common language in Iran (Farsi) and the year the Islamic Republic was founded (1979). We asked two multiple-choice questions, "The word 'mullah' is best translated as Leader, Dictator, Priest, or General," and "Which of the following countries does NOT share a border with Iran? Afghanistan, Iraq, Kazakhstan, Pakistan, or Turkey.”

Vignettes. Participants read a brief and accurate historical account of Iran, beginning with Cyrus the Great, the $11^{\text {th }}$ century Turkish invasion and Genghis Khan's Mongol invasion. When the account reached the $20^{\text {th }}$ century, the manipulations (and historical inaccuracies) were introduced. In Study 2a, the vignettes gave substantial information about the ally status of Iran and the U.S. (which changed from 1970s to the 1980s), but introduced no information about Iran's level of democracy. In Study 2b, the vignettes gave substantial information about Iran's democracy level, but gave no information about relations with the US.

At the end of each vignette, to separate what they might know of Iran-U.S. relations today, participants were told "A lot of time has elapsed since the 1980's and change continued to take place in Iran over the years," and "Iran continues to be an important player of on the world stage."

Dependent variables. For Study 2a, the critical dependent variable read "How much of an ally was Iran to the United States?" with a 1-4 response scale labeled "Not an ally at all" (1), "A 
limited ally" (2), A partial ally" (3), and "A major ally" (4). This question was answered twice, once with the predicting instruction "Please answer the following questions about Iran during the 1970s [1980s], when Iran was a democracy," and one with the instructions "Please answer the following questions about Iran during the 1980s [1970s], when the country was presided over by an unelected mullah.”

For Study 2b, the critical dependent variable read "How democratic is the Iranian government?" with a 1-4 response scale labeled “No democracy at all” (1), “A very limited democracy“ (2), "A partial democracy" (3), and "A complete democracy" (4). This question was answered twice, once with the predicting instruction "Please answer the following questions about Iran during the 1970s, when the USA and Iran were allies. [... when the US and Iran were not allies]" and one with the instructions "Please answer the following questions about Iran during the 1980s, when the alliance between the country had ended ... when the US and Iran had become allies]."

\section{Results and Discussion}

Knowledge. Knowledge of Iran was very low, with a modal score of zero (50.8\% of participants, mean $=0.76 \%$ correct), and only $5.1 \%$ of participants answered all four correctly. Most participants did not have enough knowledge to reject our version of Iranian history. (Results were virtually identical when knowledgeable participants were removed; no participants were dropped for these analyses.)

For both Studies $2 \mathrm{a}$ and $2 \mathrm{~b}$, the main dependent variable was analyzed with a 2 (Decade) $\mathrm{X} 2$ (Ally/Democracy status) mixed model ANOVA. Because in both studies the critical test is between decades (but different decades for the two conditions), the interaction term is the 
appropriate hypothesis test; the two main effects test the effect of counterbalancing. The results are displayed in Figures 2a and $2 \mathrm{~b}$.

Inferring ally status from democracy. For Study 2a, there was no main effect comparing democracy status in the $1970 \mathrm{~s}$ vs. the $1980 \mathrm{~s}, F(1,49)=2.44, p=.125$, and the order in which democracy vs. autocracy occurred, $F<1$. The hypothesized interaction occurred, $F(1,49)=5.24$, $p=.026, \eta=.31$, see Figure $2 \mathrm{a}$. Participants tended to perceive Iran as an ally when it was a democracy, as compared to when it was an autocracy.

Inferring democracy from ally status. For Study $2 \mathrm{~b}$, there was no main effect comparing ally status in the 1970 s vs. the 1980 s, and the order in which ally vs. adversary occurred, both $F$ 's $<1$. The hypothesized interaction occurred, $F(1,57)=21.50, p<.0001, \eta=.57$, see Figure $2 \mathrm{~b}$. Participants tended to perceive Iran as a democracy when it was an ally, as compared to when it was not.

Studies $2 \mathrm{a}$ and $2 \mathrm{~b}$ show that our participants inferred quite strongly and reliably that democracy and being an ally of the U.S. go hand-in-hand. These two studies show that knowing a country is a democracy causes US students to believe that country is our ally, and conversely, knowing that a country is our ally causes them to believe that country is a democracy. Our participants showed a reliable pattern of perceiving consistency—good things (e.g., democracy) belong with other good things (e.g., alliance with the US).

These data have an ironic flavor, as the particular history of relations between the US and Iran is a counter-example to the experiment. The period of time since WWII of closest relations between the US and Iran coincide with the period of least democracy in Iran (Abrahamian, 2013; Patrikarakos, 2013). The era preceding our closest relations (prior to the 1953 US-sponsored coup) and the era of mutual discontent (from the 1979 Islamic Revolution to the present) 
represent a syncretic blend of constitutional democracy and theocracy (Juergensmeyer, 2008). Nevertheless, our participants intuited exactly the opposite of reality, as a way of maintaining consistency between ally and democracy status. The US does not exclusively seek for allies among democracies; our participants behave as if this might be so.

\section{Study 3: Democratic Warfare and US Covert Action}

To restate the PToL, US citizens view democracy as good, and people in democracies are in unit relationship with their governments, so people in democracies are good. War is not good, so war against democracies creates inconsistency, and is thus illegitimate. To preserve legitimacy and engage in militarized hostilities toward another democracy, a democratic nation may (1) deny that it is a democracy, (2) deny that its target is a democracy, or (3) hide its actions from the public. The first option is comparatively rare, the second option is popular (e.g., British response to Falklands/Malvinas invasion) but is not always possible (Kim \& Hundt, 2012). We investigated the third option, and compared overt and covert militaristic actions by the US to assess the level of democracy of the nations targeted by those actions. We hypothesize that the US engages in overt militarized international disputes or international war at a significantly greater rate against non-democracies than against democracies, but when the United States uses force against democracies, it will use covert force at greater rate than against nondemocracies. ${ }^{3}$

Method

\footnotetext{
3 The 1991 Intelligence Authorization Act defines covert action as "an activity or activities conducted by an element of the United States Government to influence political, economic, or military conditions abroad so that the role of the United States Government is not intended to be apparent or acknowledge publicly" (Scott 2004). This broad sense includes the use of covert military force as well as clandestine efforts by the US government to influence events in another democracy through instigation of violence or support for the use of force again a democratically elected government by the indigenous forces in the target state.
} 
We used the Correlates of War Project (CoW; Ghoson \& Palmer, 2003) to define the overt occurrences of militarized inter-state disputes (MID), the Polity IV dataset (Gurr, Jaggers, and Moore, 1989; Marshall and Jaggers, 2005) to ascertain the level of democracy of nations involved in the disputes (on a $0-10$ scale), and developed our own database of US-involved covert military operations from 1949 to 2000.

\section{Measuring Overt Military Operations}

The CoW (Ghoson \& Palmer 2003) lists all countries taking part in the dispute and the hostility level reached in this dispute. Hostility level ranged from 1 , no militarized dispute, to 5 , open war. Disputes rated 2 (threat of force) and higher were included in the analysis; this is a conservative estimate that errs on the side of the null hypothesis because it includes minor acts of aggression that the general public are less likely to pay attention to. The low level acts of aggression were included, however, as a match to the covert actions, which often fall far short of full-scale war. We followed the most common practice and used the combined Polity IV democracy-autocracy score to determine a country's level of democracy (Bogaards, 2012).

\section{Measuring Covert Military Operations}

No comprehensive dataset was available that listed covert interventions taken by the US against foreign nations with a reliable classification of the use of force as "covert", we set out to create our own ${ }^{4}$. To generate the list, we consulted several historical accounts of the Central Intelligence Agency (CIA) and US interventions. To be included in the database, each action had to be considered a true intervention by at least three separate sources and needed to achieve a level of action as high or higher than threat of force (that is a standard comparable to the one used for overt MIDs).

\footnotetext{
${ }^{4}$ Downes \& Lilley (2010), Forthythe (1992), and Van Evera (1990a) rely on declassified intelligence information in their qualitative studies of covert military acts without specifying the rules of inclusion/exclusion of the incidents.
} 
To establish that the US intervention should indeed be considered covert, we developed a two-prong test. First, an action must have not also been listed as an MID by the CoW. Second, the covert actions identified in historical accounts and not listed in the CoW project were examined for major press coverage. Two research assistants, working independently, searched for news articles in New York Times and Washington Post relating to the actions, ranging from the time the action took place until a year after the action ended.

Research assistants rated the level of "covertness" of each action, based on whether the action was mentioned at all in the newspapers, if it was mentioned as a US action, and if the US government took responsibility for the action. To be considered covert, actions had to either receive no mentions in either newspaper, or if the action was mentioned, the description must lack any connection to the US in the reporting. US involvement was scored as "covert" only if the US government denied involvement in the action. This method identified 27 cases of US covert intervention; they are enumerated in Table 2.

$\underline{\text { Results and Discussion }}$

Table 3 displays the 27 covert actions and 231 overt MIDs by democracy status. Table 3 differentiates between democracies and non-democracies in two ways. We defined democracies by an "inclusive" standard, with democracies scoring 0 or above on their Polity IV values, and we also defined democracies by a "strict" standard, using democracy scores of 7 and above ${ }^{5}$.

Covert interventions in our dataset were comparatively rare, representing about $10 \%$ of all US interventions. (Some covert military actions may have occurred that are not included in Table 2, as by their very nature, the actions were concealed.) U.S. aggression against

\footnotetext{
${ }^{5}$ Although a score of 7 is relatively arbitrary, there exists no standard way of classifying countries in the relevant literature (for further discussion, see Bennett, 2006). What matters is that governmental elites are likely to see the country as democratic enough to anticipate objections from the public.
} 
democracies was rare, ranging somewhere between $6-14 \%$ of all interventions, depending upon the standard.

Nearly $90 \%$ of all US military interventions were overt, and using the inclusive standard, we found that against non-democracies this rate was about $94 \%$. By contrast, covert operations were significantly more likely when intervening against democracies; although $6.3 \%$ of interventions against non-democracies were carried out covertly, a much larger $37 \%$ of interventions against democracies were carried out covertly, $\chi_{(I d f)}^{2}=30.76, p<.0001$. Alternatively, the US acted overtly almost $95 \%$ of the time when aggressing against nondemocracies compared to just $63 \%$ of the time it aggressed against democracies.

Using the strict standard, the United States overt actions accounted for $91 \%$ of the interventions against non-democracies, compared to just $71 \%$ of the time it aggressed against democracies. Covert operations were again more likely to be used against democracies, representing $29 \%$ of all interventions, as compared to $9 \%$ of interventions against nondemocracies, $\chi_{(I d f)}^{2}=6.97, p=.008$.

If we treat democracy as a continuous variable, the correlation between overt/covert status and level of democracy is $r_{p b}=.36, N=258, p<.0001$. This provides an estimate of a fairly substantial effect size of democracy on enhancing the probability of a covert intervention.

This continuous analysis is statistically stronger than those that rely on artificially dichotomized variables, but it highlights one aspect of our data set that needs discussion. The unit of statistical analysis is the historical incident, and it occasionally relies on more than one incident from the same country. For the 27 covert incidents, 22 countries are involved, five of which had two incidents, and all the rest had only one. For the 231 overt incidents, 40 countries are represented, of which 22 had two or more. Although the incidents are statistically 
independent of each other for their overt/covert status, they are not independent with respect to democracy level (especially if those incidents occurred in the same year, for which only one Polity IV value exists). To solve this problem, we calculated average level of democracy and average level of covertness within nation (across all incidents; some nations received both overt and covert operations). This leaves 52 separate countries, with $r=.29, p=.037$, between the level of covertness and level of democracy. Whether analyzed at the level of incident or at the level of nation, as the democracy level of the target nation goes up, so too does the probability of a US intervention being carried out covertly—strong evidence in support of the clandestine hypothesis.

\section{Study 4: Democracy and Detention in the "War on Terror"}

We now apply the PToL and the issue of democratic peace to the treatment of individuals from democracies and non-democracies. The US detention and interrogation policies applied to the so-called "enemy combatants" detained over the course of the "war on terrorism" have been a highly contentious issue (Cole, 2013). A result of the wartime decision making formalized in a series of presidential orders, memorandums, and legal memos, these policies contain guidelines for classifying lawful and unlawful combatants and allow for trials of the latter category of detainees in military tribunals, deny them the protection of the Geneva Conventions, and authorize the implementation of enhanced interrogation techniques against these prisoners by the US military personnel (Pfiffner 2009). Most of the individuals detained by the US military on the order of the US administration were placed in the Guantanamo Bay detention camp (Gitmo) established at the Guantanamo Bay Naval Base, Cuba, and controlled by the US. Those detained during the war in Iraq were transferred to Abu Ghraib. In parallel to the US military operations, the CIA seized a number of persons in foreign territories suspected of hostile actions against the 
US. Held incommunicado and without due process of law, these individuals were either placed in the CIA secret prisons ("Black Sites"), or transferred to states known for forced disappearances and torture (Boys, 2011; Forsythe, 2011), known as "extraordinary rendition."

We studied people detained between 2001-2006 inclusive, sent either to Gitmo or extraordinary rendition. This was the period of widest interception and detention of prisoners, and in the case of prisoners sent to Gitmo are a matter of public record; the US Department of Defense released prisoner records on the Internet. By contrast, extraordinary rendition was a very secretive process; the US government has not released official records (Grey, 2006; Mayer, 2005; Senate Select Committee, 2012/2014).

The choice between rendition and Guantanamo is a choice between covert and overt detention. This represents - at the individual level — the same choice of action as in the Study 3. When aggressive, war-like treatment of individuals takes place overtly, detainees are imprisoned where scrutiny is possible. When war-like treatment of individuals takes place covertly, detainees are handled away from public scrutiny.

We hypothesize that when people were detained in the "war on terror," their subsequent treatment would be based partly on the democracy level of their country of origin. Because detention/ interrogation can be conceptualized as war at the individual level, the PToL suggests that the most vigorous forms of interrogation are not appropriate for "good" citizens of democracies. For these detainees, the US government will try to hide their interrogation and detention by having them subject to extraordinary rendition. We hypothesize that detainees from a democracy, ironically, are more likely to be subjected to extraordinary rendition than sent to Guantanamo Bay; suspects from non-democracies will be more likely to be publicly sent to Gitmo. 
Method

Participants in this study were in a very real sense unwilling — detainees picked up by the US in its "war on terror." The detainees consisted of two separate groups for comparison and were obtained through two separated sources. The first group of detainees was those being held at the US detention camp at the Guantanamo Bay Naval Base on the island of Cuba. Information concerning these detainees was obtained through a United States Department of Defense document procured off of their website (U.S. D.O.D., 2006). This list provided the names of 754 individuals detained at Guantanamo Bay between January 2002 and May 2006, and also provided the detainee's country of citizenship.

The second group of detainees was those that the US government had detained and rendered through the process of extraordinary rendition. Because extraordinary rendition operates covertly, the US Government does not provide online lists of those rendered. Instead, an accounting of rendered "participants" was obtained through a list based on reports from Human Rights Watch, Amnesty International, the ACLU, the Center for Human Rights and Global Justice at NYU, Guantanamo Files (Worthington, 2007) and Ghost Plane (Grey, 2006), and published online by Mother Jones (Bergen, 2008). This list named 53 individuals subject to extraordinary rendition from 2001-2006 (same window as for Gitmo). The list provided where they were rendered from and to, dates of the rendition, and detainee's country of origin.

We used the Polity IV dataset to determine the detainees' countries' level of democracy (for the year of detention), using the same strict and inclusive standards as in Study 2. A small number of detainees carried passports from two nations, and these nations did not share the same Polity IV values. In these cases (e.g., Syrian-Spanish), we always used the higher democracy 
level (e.g., Spain); the treatment of democracies that is the critical element in the PToL's view of DPT.

$\underline{\text { Results and Discussion }}$

We identified 807 people detained by the U.S. government in the "War on Terror;" they are categorized in Table 4 by democracy and detention status. Table 4 again differentiates between democracies and non-democracies using both an "inclusive" standard (democracy defined at 0 or above on Polity IV values), and a "strict" standard, (democracy defined at 7 or above). Extraordinary renditions made up just $6.6 \%$ of our detainee dataset.

Over $90 \%$ of all detainees were sent to GITMO, and using the inclusive standard, we found that for detainees from non-democracies this rate was about $95 \%$. By contrast, being extraordinarily rendered was significantly more likely when detainees were from democracies. About $5 \%$ of detainees from non-democracies were sent into extraordinary rendition, $21.2 \%$ of detainees from democracies were subject to extraordinary rendition, $\chi_{(I d f)}^{2}=33.04, p<.001$.

Using the strict standard, the US sent detainees from non-democracies to GITMO in about $95 \%$ of the cases in which they were detained, compared to just under $77 \%$ of the time when detainees were from democracies. Extraordinary rendition was still more likely to be used against detainees from democracies, representing over $23 \%$ of all detentions, as compared to only $5.4 \%$ from non-democracies, $\chi_{(I d f)}^{2}=24.69, p<.001$. The U.S. is substantially more likely to use extraordinary rendition for detainees from democracies.

Because the list of detainees subjected to extraordinary rendition is less reliable than the list of Guantanamo detainees, we explicitly considered unreliability as a cause of our results. It is possible that the available data is biased in favor of under-reporting of individuals from nondemocracies who were extraordinarily rendered (e.g., citizens of failed states may go 
unreported). To address this, we ran a "file drawer" test, a calculation to see how many detainees from non-democracies would be necessary to add to our observed rendition data to create statistical non-significance. An additional 62 unreported detainees from non-democracies would be necessary for the results fall above the .05 level. This amount is nearly triple the size of the observed sample; a biased sample is an unlikely account.

Our data demonstrate an ironic disadvantage of democracy; the possession of a passport from a democracy substantially increases one's chances, once detained, to be sent to the less desirable extraordinary rendition. As predicted by PToL and the clandestine account of DPT, citizens from democracies were treated with high rates of covert detention.

\section{General Discussion}

These studies offer some compelling insights into the behavior of the US in relation to DPT. In our first study, we established that individuals do indeed tend to balance their perceptions of the US, its allies, and their levels of democracy. In our second study, we showed that democracy and alliance with the US go hand-in-hand as a way of maintaining consistency; Americans see democracy in their allies, and they see alliance with other democracies. These sentiments of a democratic public, we argue, represent a constraint on decision makers. In the third study, we hypothesized that a logical consequence of citizens' tendency toward perceptual balance on the international stage would result in a parallel tendency for the US to prefer covert action as the means of intervening against more democratic countries. We found that the US is more likely to use covert intervention against democracies than against non-democracies. In our fourth study, we extended this behavioral tendency to the treatment of captured suspects in the "war on terror". We found that the US more often pursues covert detention against detainees from democracies than from non-democracies. 
We argue that these foreign policy choices are rooted in US elites' desire to avoid negative public sentiment, which in turn, is rooted in cognitive consistency, a premise of the PToL. Hayes' (2012) and Weart's (1998) analyses of democratic peace have illuminated how the needs for cognitive consistency affect perceptions of citizens and elites and constrain decisionmakers' belligerent choices toward fellow democracies. These studies represent a helpful advance in articulating the plausible normative explanations of democratic peace focusing on public constraint and elite preference formation. By integrating the PToL with DPT, our study pushes this research agenda forward by explicating how perceptions of legitimacy are created and sustained in democratic states, and by showing how these perceptions serve as constraints on elites pondering a military solution to a dispute with another democracy and thus, inadvertently, prompting them to resort to clandestine subversive behavior and the use of covert military force.

PToL emphasizes consistency among relations in the simplest terms; the principle that "bad people deserve bad treatment ... and good people deserve good treatment (Crandall and Beasley 2001, p.79)" is fundamental to judgments of justice and legitimacy. This simple balancing of moral affect and treatment—structural balance—provides a basis for understanding the mechanisms of DPT (see also Hart, 1974). Citizens of democracies are from "good" countries that are US allies, and the close relationship between democratic citizens and their nation mandate good treatment. When US government policy and interests lead to harsh treatment of democratic citizens, the government risks its legitimacy. To preserve legitimacy it hides its actions, prosecuting wars and detainees in the twilight.

These support the "clandestine" hypothesis advanced in this research and the perceptual logic of DPT suggested in the paper. We might consider the 1953 coup d'état in Iran orchestrated by the US and UK, or the 1954 Guatemalan coup d'état that deposed the democratically-elected 
president by an anti-Communist "army" recruited, trained, and armed by the CIA, or the "secret wars" of the Reagan Administration against the Sandinista government in Nicaragua as illustrations of this logic. The clandestine war cases were selected for their "covertness", i.e., these operations were either silenced in press or, if mentioned in newspaper reports, ruled out any connection between the US and the violence. The cases also indicate the concern of the US leaders with public opinion and the fear of political and reputational consequences for an unpopular attack on another democratic state. In some instances, elites from both the invading and target states were aware of the nature and goals of the covert use of force and this information can sometimes leak to the target country's population. The only populace that remains reliably ambivalent or misinformed is the general US public.

Governments might attempt to affect public perception of a potential target of aggression to engender public support for the use of force. The histories of both covert and overt military operations provide a wealth of evidence of the manipulation of public opinion to win citizens' hearts and minds. In 1954, the Eisenhower Administration engineered public consent for a Guatemalan coup d'état using a public relations campaign in the North American press. Fearmongering propaganda about the "communist leanings" of the Guatemalan president—a "puppet of the Soviet Union"-created a negative and fearful perception of the Guatemalan regime in American minds. The American news media subsequently misrepresented the coup as a successful restoration of democracy in Guatemala, carried out by local freedom fighters. The fact that the CIA had masterminded and funded the revolt was excluded from the news (Gleijeses 1992). This and other historical cases of the intelligent use of propaganda (the British government, for example, used the BBS's Persian service for advancing its anti-Mosaddegh agenda in pre-1953 Iran) comport with the logic of the governments" "clandestine" actions 
against other democratic states. Since the democratic governments are both constrained by and concerned with their popular legitimacy, they will engage in acts of coercion against other democracy only to the extent that they are able to make their actions seem legitimate through the elaborate myths of legitimation and/or conceal them. Whether the government creates these public perceptions is beyond the scope of this paper, but our studies provide evidence that the US government may be taking public perception into account when crafting its foreign policy action.

Certainly other Western liberal democracies have been implicated in direct and indirect support of covert operations against other democratic states. Following the Second World War, the US and UK set up a network of paramilitary forces for countering possible invasion of the armies of states from the Warsaw Pact. During the Cold War, these networks were turned into what became known as NATO's "secret armies" operated by the military intelligence services of European states. Trained in covert operation and subversion techniques, these armies were used in a series of clandestine violent actions against "threatening" regimes—often democratic—in Europe and other parts of the world (Ganser 2005).

Legitimacy is important to authorities because it allows them the ability to act and have their actions supported more easily than if it is absent. A government that lacks legitimacy must then rely on force to get its citizens to comply with its actions and policies. For these reasons it is desirable for a government to try and maintain its legitimacy by acting consistently with public perception, and when its actions are out of step with the public's opinion it will attempt to hide those actions so their legitimacy is not questioned.

The normative constraints from the public, however, could conceivable apply at the elite levels as well. Kim and Kundt (2012) analyze the case of US covert intervention in Chile and develop hypotheses regarding democratic peace by examining just this interaction between the 
normative demands of popular opinion and the institutionally-bound constraints afforded potentially belligerent democracies. They argue that the US intervention in democratic Chile was covert precisely because of a prevailing public mood opposed to military ventures. They go on to consider that "... a path to regime change typified by covert action rather than open warfare implies a lower degree of cohesion within the policy-making elite....some elites in the State Department opposed the intervention in Chile on philosophical grounds. It seems that one of the reasons why the elites undertook covert operations was to circumvent normative restraints." Although we have not sought to test elite perceptions of legitimacy, the intriguing possibility persists that policy divisions — inspired by debate born of questions of legitimacy—could, somewhat ironically, result in covert actions.

Our findings also have implications for post-covert action behavior once a covert operation is revealed. If balance is an operational factor, we would expect to see concerted efforts to justify the behavior by realigning public sentiments. This might take the form of denying the democratic qualities of the target: "When it was no longer feasible to conceal their involvement in Chile, US elites attempted to depict Allende as an evil figure.” (Kim \& Kundt, p. 65). This denigration matches hostile action with an evil figure, and thus restores balance and preserves legitimacy.

Democratic peace has given rise to a great deal of scholarly debate in part because of its potential implications for the dominant theories in international relations. If democracies avoid war with other democracies, realist theories are presumably weakened. Driven by the mandates of anarchy and self-interests, realist accounts of state behavior do not well tolerate varying standards of behavior for different potential adversaries based on type of government. Liberal theories, on the other hand, allow more room for cooperation under anarchy, given the right 
circumstances. If democratic dyads behave no differently than any other type of dyad, a substantial empirical asset is potentially lost to the self-help, self-interest version of international affairs purported by realism.

The studies presented here cannot hope to fully adjudicate such a foundational and enduring debate. Rather, we offer a psychological perspective that might help account for states' strategies. Democratic states pursue their national interests, but they appear to do so with deference to the powerful normative influence of public perceptions. Whether elites wring their hands over potential breaches of the democratic covenant is open for debate, but US foreign policy behavior seems to suggest deep recognition of the consequences of such breaches. Why hide these acts from the public? Of course, covert action is not undertaken for the sole purpose of hiding acts from the US public. There are many audiences to international relations. But why would we expect a different rate of use of covert force toward democracies than toward nondemocracies? Such an argument has more trouble explaining our extraordinary rendition findings, where the detention itself is a fait accompli and the rendition itself (we argue) merely acts to remove the detainee from the public spotlight.

Although many have seen the fact of non-war aggression between democracies as an indication that the so-called "law" of international relations is suspect, we disagree. Covert violence, we argue, results from elites who are constrained by public sentiments, which themselves are rooted in a need for perceptual consistency. As citizens become aware of the inconsistencies between their value of peaceful conflict resolution, on the one hand, and the aggressive behaviors of their own government, on the other, the great democratic experiment itself becomes unbalanced. Covert policies are the sometimes result of the competing mandates of perceived national interests countered by the constraining force of democratic values. When 
elite actors wish to pursue a policy at odds with the democratic peace, to preserve their legitimacy they engage in hostilities clandestinely. 


\section{References}

Abrahamian, E. (2013). The coup: 1953, the CIA, and the roots of modern US-Iranian relations. New York: New Press.

Beasley, R. \& Crandall, C. (2004). Allawi's “violent past:” A signal of future peace? Dialogue, 19(2), 11.

Bennett, S. (2006). Toward a continuous specification of the democracy-autocracy connection. International Studies Quarterly 50, 313-38.

Bergen, P (2008, March 3). Disappearing act: Rendition by the numbers. Mother Jones, 33(2), Retrieved from http://www.motherjones.com/politics/2008/03/disappearing-actrendition-numbers.

Blum, W. (1995). Killing hope: U.S. military and CIA interventions since World War II. Monroe, Maine: Common Courage Press.

Bogaards, M. (2012). Where to draw the line? From degree to dichotomy in measures of democracy. Democratization, 19, 690-712.

Boys, J. D. (2011). What's so extraordinary about rendition?. The International Journal of Human Rights, 15, 589-604.

Crandall, C. S., \& Beasley, R. K. (2001). A perceptual theory of legitimacy: Politics, prejudice, social institutions, and moral value. In J. Jost and B. Major (Eds.) The psychology of legitimacy (pp. 121-145). New York: Cambridge University Press.

Crandall, C.S., Silvia, P.J., N'Gbala, A.N., Tsang, J. \& Dawson, K. (2007). Balance theory, unit relations, and attribution: The underlying integrity of Heiderian theory. Review of General Psychology, 11, 12-30.

Davenport, C., \& Armstrong, D.A. (2004). "Democracy and the violation of human rights: A statistical analysis from 1976 to 1996." American Journal of Political Science 48(3), 538554.

DeMesquita, B.B., Morrow, J. D., Siverson, R.M., \& Smith, A. (1999). An institutional explanation of the democratic peace. American Political Science Review, 791-807.

Diamond, L. (1999). Developing democracy: Toward consolidation. Johns Hopkins University Press.

Downes, A.B., \& Lilley, M.L. (2010). Overt peace, covert war?: Covert intervention and the democratic peace. Security Studies 19, 266-306.

Doyle, M. W. (2005). Three pillars of the liberal peace. American Political Science Review, 463-466. 
Doyle, M. On the Democratic Peace. International Security, 19:4, 180-184.

European Parliament (2007). European Parliament resolution on the alleged use of European countries by the CIA for the transportation and illegal detention of prisoners. 2006/2200(INI).

Falomir-Pichastor, J. M., Pereira, A., Staerklé, C., \& Butera, F. (2011). Do all lives have the same value? Support for international military interventions as a function of political system and public opinion of target states. Group Processes \& Intergroup Relations, 15(3) 347-362.

Falomir-Pichastor, J.M., Staerklé, C., Pereira, A., \& Butera, F. (2012). Democracy as justification for waging war. Social Psychological and Personality Science, 3, 324-332.

Forsythe, D.P. (1992). Democracy, war, and covert action. Journal of Peace Research, 385-395.

Ganser, D. (2005). NATO's Secret Armies: Operation Gladio and Terrorism in Western Europe. New York: Frank Cass.

Ghosn, F, \& Palmer, P. (2003) Codebook for the Militarized Interstate Dispute Data, Version 3.0. Available from http://www.correlatesofwar.org/.

Gleijeses, P. 1992. Shattered hope: The Guatemalan Revolution and the United States, 19441954. Princeton, NJ: Princeton University Press.

Goldstein, J.S. (2011). Think again: War. Foreign Policy. Sept/Oct 2011.

Grey, S. (2006). Ghost plane: The true story of the CIA torture program. New York: St. Martin's Press.

Gurr, T.R., Jaggers, K. \& Moore, W.H. (1989). Polity II codebook. Boulder, CO: Center for Comparative Politics, University of Colorado.

Hart, J. (1974). Symmetry and polarization in the European international system, 1870-1879: A methodological study. Journal of Peace Research, 229-244.

Hayes, J. (2012). Securitization, social identity, and democratic security: Nixon, India, and the ties that bind. International Organization, 66, 63-93

Heider, F. (1958). The psychology of interpersonal relations. New York: Wiley.

Heider, F. (1990). Fritz Heider: Notebooks: Vol. 6. Units and coinciding München-Weinheim, Germany: Psychologie-Verlags Union. 
Henderson, E. (2002) Democracy and war: the end of an illusion? Boulder, CO: Lynner-Riener.

Herrmann, R. (1988). The empirical challenge of the cognitive revolution: A strategy for drawing inferences about perceptions. International Studies Quarterly, 175-203.

Holmes, J.E., 1985. The mood/interest theory of American foreign policy. Lexington: University Press of Kentucky.

Ish-Shalom, P. (2008). Theorization, harm, and the democratic imperative: lessons from the politicization of the democratic-peace thesis. International Studies Review, 10, 680-692.

James, P., \& Mitchell, G.E. (1995). Targets of covert pressure: The hidden victims of the democratic peace. International Interactions 21, 85-107.

Jervis, R. (1976) Perception and Misperception in International Politics. Princeton, NJ: University Press.

Juergensmeyer, M. (2008). Global rebellion: Religious challenges to the secular state, from Christian militias to al Qaeda (Vol.16). Berkeley: University of California Press.

Kegley, C.W. \& Hermann, M.G. (1995). The political psychology of "peace through democratization." Cooperation and Conflict, 30, 5-30.

Kim, J. (2005). Democratic Peace and Covert War: A Case Study of the U.S. Covert War in Chile. Journal of International and Area Studies 12(1), 25-47.

Kim, J., \& Hundt, D. (2012). Popular consent and foreign policy choices: war against the Philippines and covert action in Chile. Australian Journal of International Affairs, 66, 52-69.

Kinsella, D. (2005) No rest for the democratic peace. American Political Science Review, 19, 453-457.

Kulish, N. (2012, Dec. 14). Court Finds Rights Violation in C.I.A. Rendition Case. New York Times, p.A12.

Layne, C. (1994). Kant or cant: The myth of the democratic peace. International Security, $5-49$.

Levy, G., \& Razin, R. (2004). It takes two: an explanation for the democratic peace. Journal of the European economic Association, 2, 1-29.

Lipset, S., M. (1959). Some social requisites of democracy: Economic development and political legitimacy. American Political Science Review, 53, 69-105. 
Macklin, A. (2008). The war on terror, extraordinary rendition, and the cost of torture. European Journal of Migration and Law, 10, 11-30.

Maoz, Z., \& Russett, B. (1993). Normative and structural causes of democratic peace, 1946-1986. American Political Science Review, 87, 624-638.

Marshall, M. G., \& Jaggers, K. (2005). Polity IV project: Political regime characteristics and transitions, 1800e2003. MD: CIDCM, University of Maryland. At http://www.cidcm.umd.edu/inscr/polity/index.htm

Mayer, J. (2005, Feb 8). Outsourcing torture: The secret history of America's "extraordinary rendition" program. The New Yorker.

Meyer, J.W. (2000). Globalization sources and effects on national states and societies. International Sociology, 15, 233-248.

Moravcsik, A. (1997). Taking preferences seriously: A liberal theory of international politics. International organization, 51, 513-553.

Morgan, T.C., \& Schwebach, V. L. (1992) Take two democracies and call me in the morning: A prescription for peace? International Interactions, 17, 305-320.

Morgan, T.C., \& Palmer, G. (2000). A model of foreign policy substitutability selecting the right tools for the job(s). Journal of Conflict Resolution, 44, 11-32.

Most, B.A., \& Starr, H. (1984). International relations theory, foreign policy substitutability, and 'nice' laws. World Politics 36, 383-40.

Oneal, J. \& Russett, B. (1999b). Assessing the liberal peace with alternative specifications: Trade still reduces conflict. Journal of Peace Research, 36, 423-442.

Oren, I. (2013). Our enemies and US: America's rivalries and the making of political science. Cornell University Press.

Owen, J. M. (1994). How liberalism produces democratic peace. International Security, 87-125.

Owen, J. (1997) Liberal peace, liberal war: American politics and international security. Cornell University Press

Palmer, G., Wohlander, S.B., \& Morgan, T.C. (2002). Give or take: Foreign aid and foreign policy substitutability. Journal of Peace Research, 39, 5-26.

Patrikarakos, D. (2013, December 9). Iran, from enemy to ally. New York Times, A33.

Prados, J. ( 2009). Safe for democracy: The secret wars of the CIA. Chicago: Ivan Dee. 
Ramsay, M. (2010). Liberal democratic politics as a form of violence. Democratization, 17235250.

Reiter, D. \& Stam, A.C. (2002). Democracies at war. Princeton University Press.

Rosato, S. (2003). The flawed logic of democratic peace theory. American Political Science Review, 97, 585-602.

Rouseea, D.L., Gelpi, C, Reiter, D. \& Huth, P.K. (1996). Assessing the dyadic nature of the democratic peace, 1918-88. American Political Science Review, 512-533.

Sen, A.K. (1999). Democracy as a universal value. Journal of Democracy, 10, 3-17.

Senate Select Committee on Intelligence. (2012/2014). Committee Study of the Central Intelligence Agency's Detention and Interrogation Program. Downloaded from http://www.intelligence.senate.gov/study2014/sscistudy1.pdf, December 5, 2014.

Sørensen, G. (1992). Kant and Processes of Democratization: Consequences for Neorealist Thought. Journal of Peace Research, 29, 397-414.

Snyder, J.L. (1978). Rationality at the brink: The role of cognitive processes in failures of deterrence. World Politics, 30, 345-365.

Tures, J.A. (2002). The dearth of jointly dyadic democratic interventions. International Studies Quarterly, 46, 579-589.

Ungerer, J.L. (2012). Assessing the progress of the Democratic Peace Research Program. International Studies Review, 14, 1-31.

United States. Committee on Armed Services United States Senate. (2008, November 20). Inquiry into the treatment of detainees in U.S. custody, Retrieved 19 December 2012: http://www.armed-services.senate.gov/Publications/Detainee Report Final_April 022 2009.pdf

United States. Department of Defense. (2006). List of Individuals Detained by the Department of Defense at Guantanamo Bay, Cuba From January 2002 through May 15, 2006. Washington, DC: Author. Retrieved from http://www.dod.mil/pubs/foi/detainees/detaineesFOIArelease15May2006.pdf

Van Evera, S. (1990). The case against intervention. The Atlantic Monthly 266(1), 72-80.

Weart, S.R. (1998). Never at war: why democracies will not fight one another. New Haven: Yale University Press.

Weissbrodt, D. \& Bergquist, A. (2006). Extraordinary Rendition: A Human Rights Analysis. Harvard Human Rights Journal, 19, 123-160. 
Worthington, A. (2007). The Guantanamo files: The stories of the 774 detainees in America's illegal prison. London: Pluto Press. 
Figure 1: Correlation of perceived ally status by perceived democracy

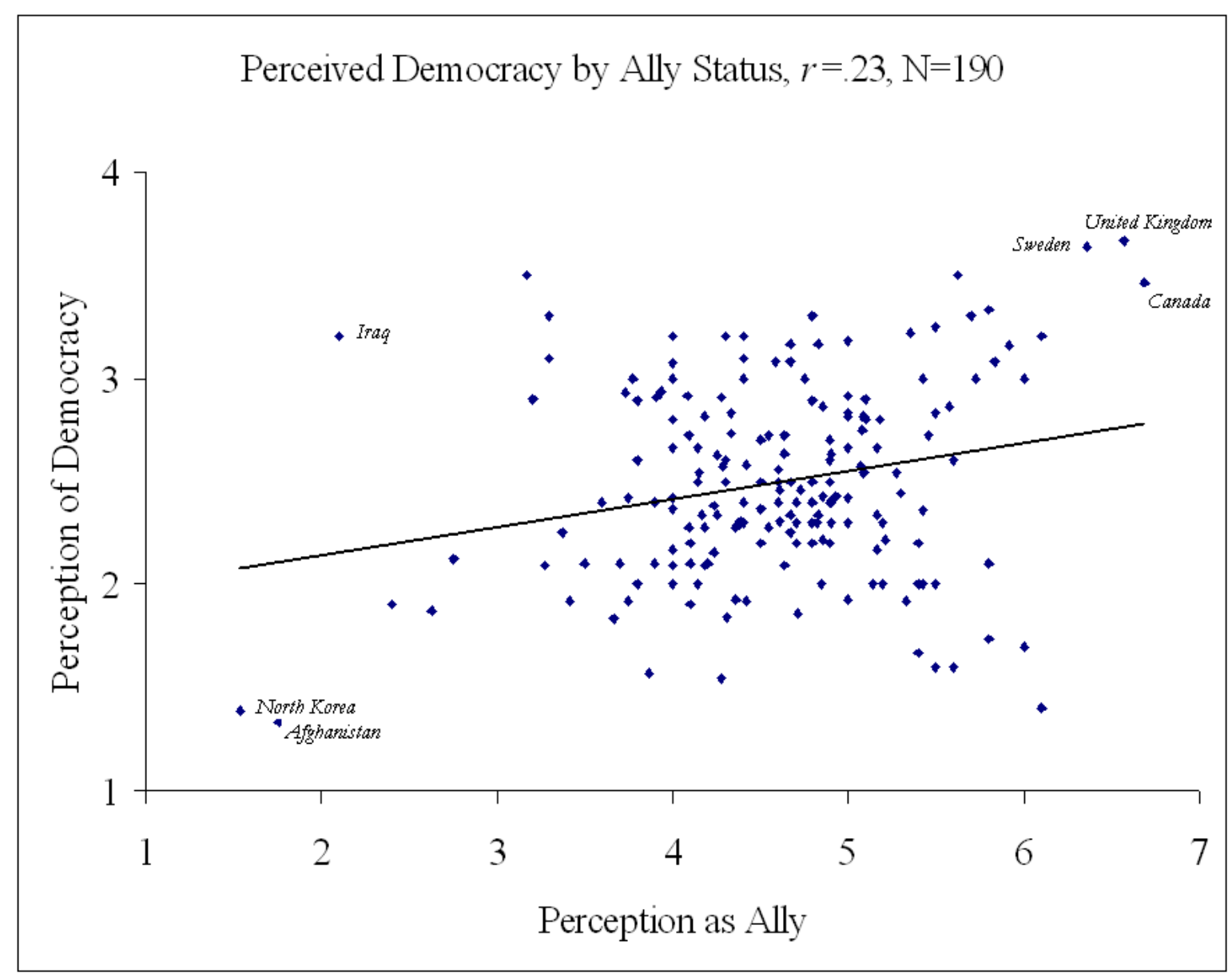


Figure 2a: Perceived democracy of Iran by U.S. Ally Status

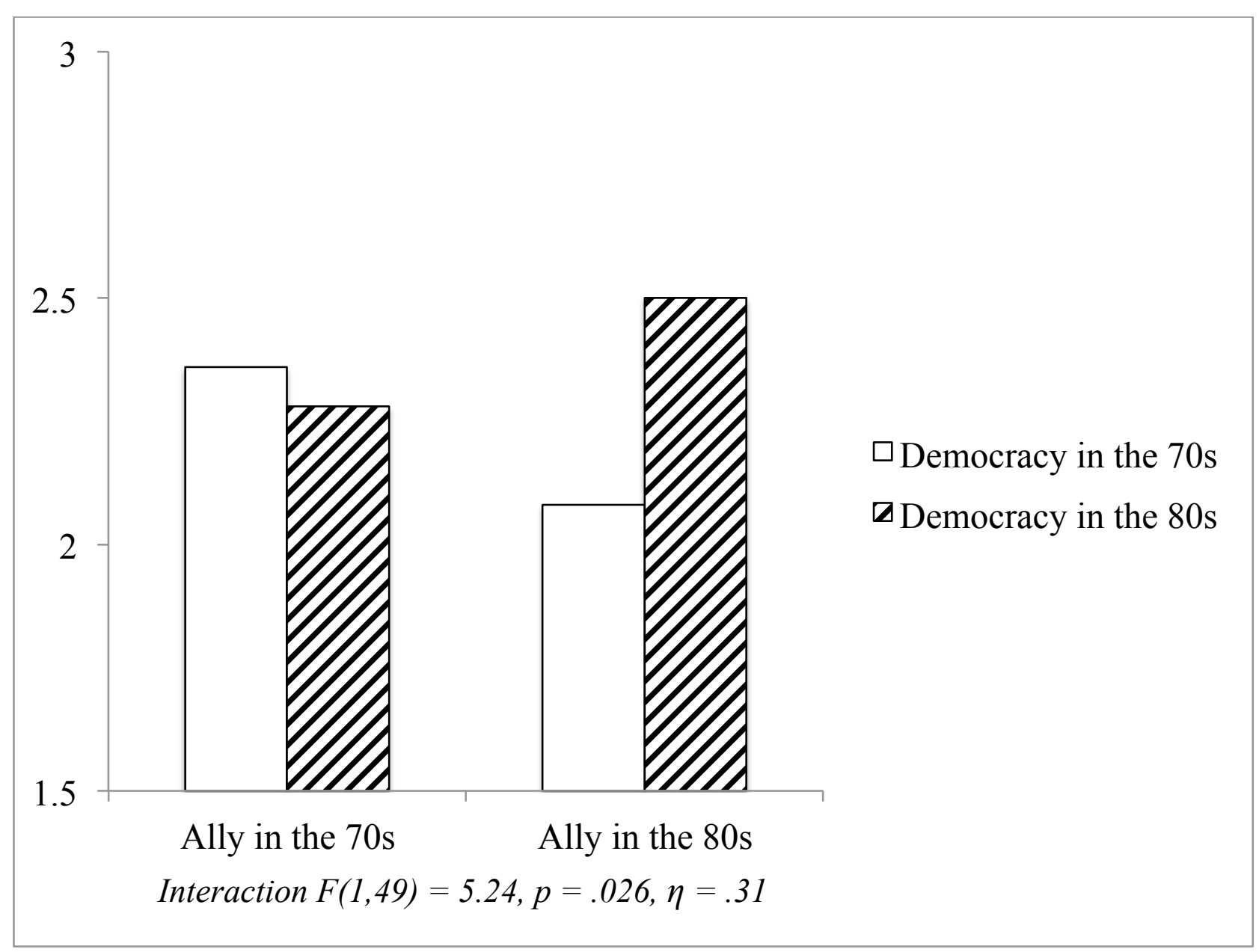


Figure 2b: Perceived U.S. Ally Status of Iran by Level of Democracy

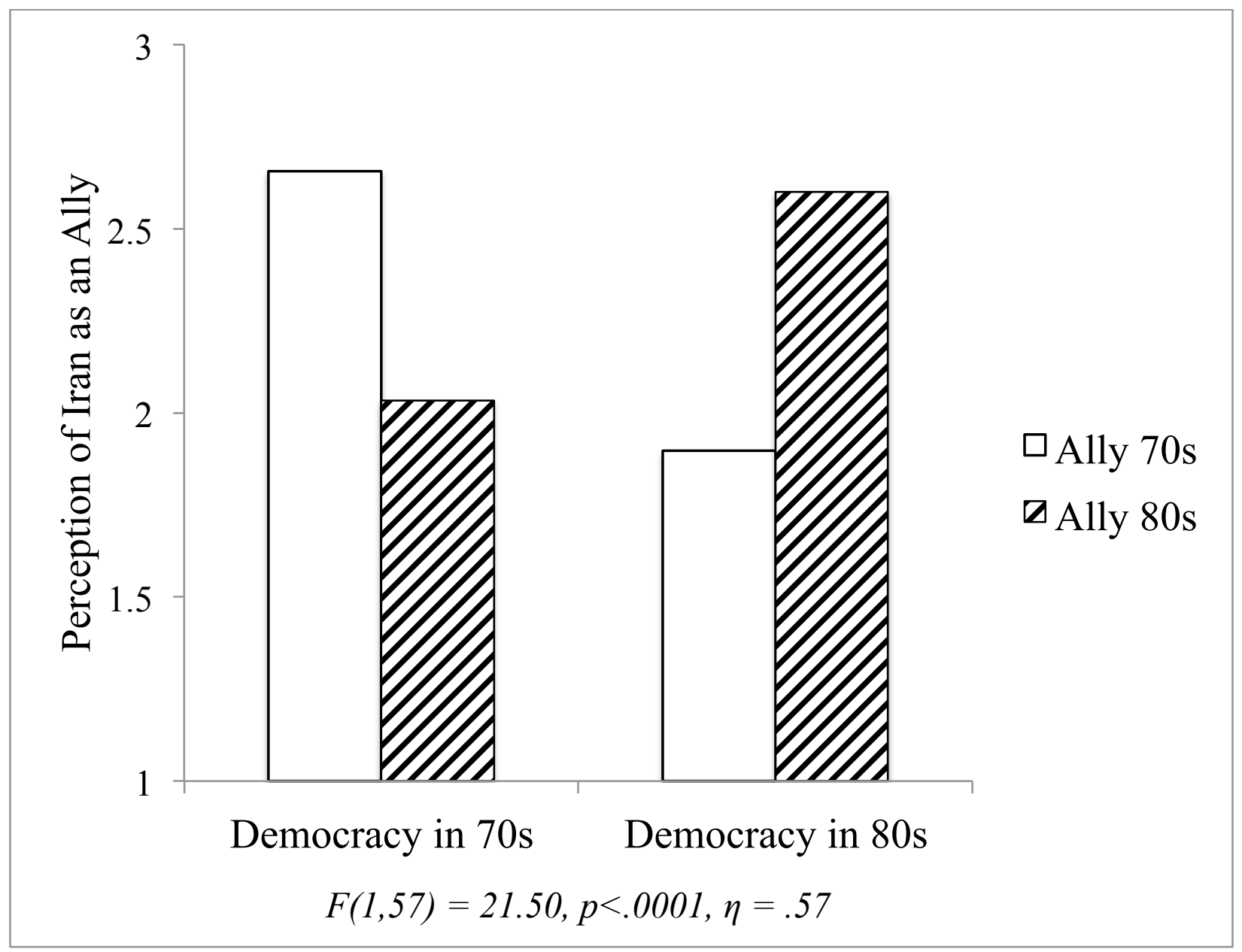


Table 1: UN Correlations, Study 1

\begin{tabular}{lccc}
\hline & Democracy & Ally & Similar \\
\hline Ally & $.23 * *$ & & \\
Similar & $.22 *$ & $.63 * *$ & \\
Important & -.01 & $.24 *$ & $.69 * *$ \\
\hline
\end{tabular}

Note: $N=190, * p<.001, * * p<.0001$ 
Table 2. U.S. Government Covert Military Actions Used in Study 2.

\begin{tabular}{|c|c|c|}
\hline $\begin{array}{l}\text { Year } \\
\text { Action } \\
\text { Began }\end{array}$ & $\begin{array}{c}\text { Main Target of } \\
\text { American Covert } \\
\text { Action }\end{array}$ & Description of Covert Action \\
\hline 1949 & Syria & Syrian coup d'état \\
\hline 1951 & Albania & Guerilla uprisings throughout country \\
\hline 1953 & Iran & Overthrow of Prime Minister Mohammad Mosaddegh \\
\hline 1954 & Guatemala & Overthrow of President Jacobo Árbenz Guzmán \\
\hline 1955 & Costa Rica & Attempted ouster of President José Figueres \\
\hline 1957 & Syria & Attempted coup d'etat, President Adib Shishakli \\
\hline 1958 & Lebanon & CIA funds pro-West politicians, U.S. forces later invade \\
\hline 1959 & China (Tibet) & CIA armed an anti-Communist insurgency \\
\hline 1959 & Haiti & Marine landing \\
\hline 1961 & Cuba & Bay of Pigs \\
\hline 1961 & Ecuador & President Jose Maria Velasco Ibarra forced to resign \\
\hline 1962 & British Guiana & Protest and general strike \\
\hline 1963 & Ecuador & Ouster of President Carlos Julio Arosemana \\
\hline 1963 & South Vietnam & Coup against President Ngô Đình Diệm \\
\hline 1964 & Brazil & Overthrow of government of President Joao Goulart \\
\hline 1965 & France & Attempted assassination of President Charles De Gaulle \\
\hline 1965 & Indonesia & Rebellion against President Sukarno \\
\hline 1966 & Guatemala & Counter-insurgency campaign \\
\hline 1966 & Ghana & Coup ousts President Kwame Nkrumah \\
\hline 1970 & Cambodia & Coup against Prince Sihanouk, 7-year bombing campaign \\
\hline 1973 & Chile & Overthrow and ouster of President Salvador Allende \\
\hline 1976 & Angola & Pro-Soviet forces battle pro-democracy forces \\
\hline 1976 & Argentina & Argentine coup d'état \\
\hline 1980 & Turkey & Turkish coup d'état \\
\hline 1984 & Nicaragua & Destabilization of Sandinistas government \\
\hline 1987 & Iran & Iran-Contra affair \\
\hline 1991 & Haiti & Military coup ousts President Jean-Bertrand Aristide \\
\hline
\end{tabular}


Table 3: Overt vs. covert actions by democracy status using two democracy standards.

\begin{tabular}{|c|c|c|c|c|}
\hline & $\mathrm{N}$ & Overt & Covert & $\begin{array}{l}\text { Ratio of Overt to } \\
\text { Covert Actions }\end{array}$ \\
\hline \multicolumn{5}{|c|}{ Inclusive Definition of Democracy } \\
\hline Non-Democracy & 223 & 209 & 14 & 14.9 \\
\hline Percentage & & $93.7 \%$ & $6.3 \%$ & \\
\hline Democracy & 35 & 22 & 13 & 1.7 \\
\hline Percentage & & $62.9 \%$ & $37.1 \%$ & \\
\hline \multicolumn{5}{|c|}{ Strict Definition of Democracy } \\
\hline Non-Democracy & 241 & 219 & 22 & 10.0 \\
\hline Percentage & & $90.9 \%$ & $9.1 \%$ & \\
\hline Democracy & 17 & 12 & 5 & 2.4 \\
\hline Percentage & & $70.6 \%$ & $29.4 \%$ & \\
\hline \multirow[t]{2}{*}{ Totals } & 258 & 231 & 27 & \\
\hline & & $89.5 \%$ & $10.5 \%$ & \\
\hline
\end{tabular}

For Inclusive definition, $\chi^{2}(1 \mathrm{df})=30.76, p<.0001$; for Strict definition, $\chi^{2}(1 \mathrm{df})=6.97, p=.008$. 
Table 4: Number of detainees held by level of democracy in nation of origin.

\begin{tabular}{ccccc}
\hline & $\mathrm{N}$ & Guantanamo & Rendition & $\begin{array}{c}\text { Ratio of Guantanamo } \\
\text { to Extraordinary Rendition }\end{array}$ \\
\hline Inclusive Definition of Democracy \\
Non-Democracy & 716 & 687 & 35 & 19.6 \\
Percentage & & $95.2 \%$ & $4.8 \%$ & 3.72 \\
Democracy & 91 & 67 & 18 & \\
Percentage & & $78.8 \%$ & $21.2 \%$ & \\
\hline
\end{tabular}

Strict Definition of Democracy

$\begin{array}{cclll}\text { Non-Democracy } & 755 & 714 & 41 & 17.4 \\ \text { Percentage } & & 94.6 \% & 5.4 \% & 3.33 \\ \text { Democracy } & 52 & 40 & 12 & \\ \text { Percentage } & & 76.9 \% & 23.1 \% & \\ \text { Totals } & 807 & 754 & 53 & \\ & & 93.4 \% & 6.6 \% & \end{array}$

For Inclusive definition, $\chi^{2}(1 \mathrm{df})=33.04 ; p<.001$, for Strict definition, $\chi^{2}(1 \mathrm{df})=24.69, p<.001$. 